\title{
INTEGRATION OF TRADITIONAL ECOLOGICAL KNOWLEDGE INTO PRIMARY SCHOOL LEARNING
}

\author{
Sumarwati, Sukarno, Atikah Anindyarini, Winda Dwi Lestari \\ Universitas Sebelas Maret, Surakarta, Indonesia \\ Jalan Ir. Sutarmi Nomor 36 A, Kentingan, Surakarta, Midle Java, Indonesia \\ Corresponding Author: watik_uns@ymail.com
}

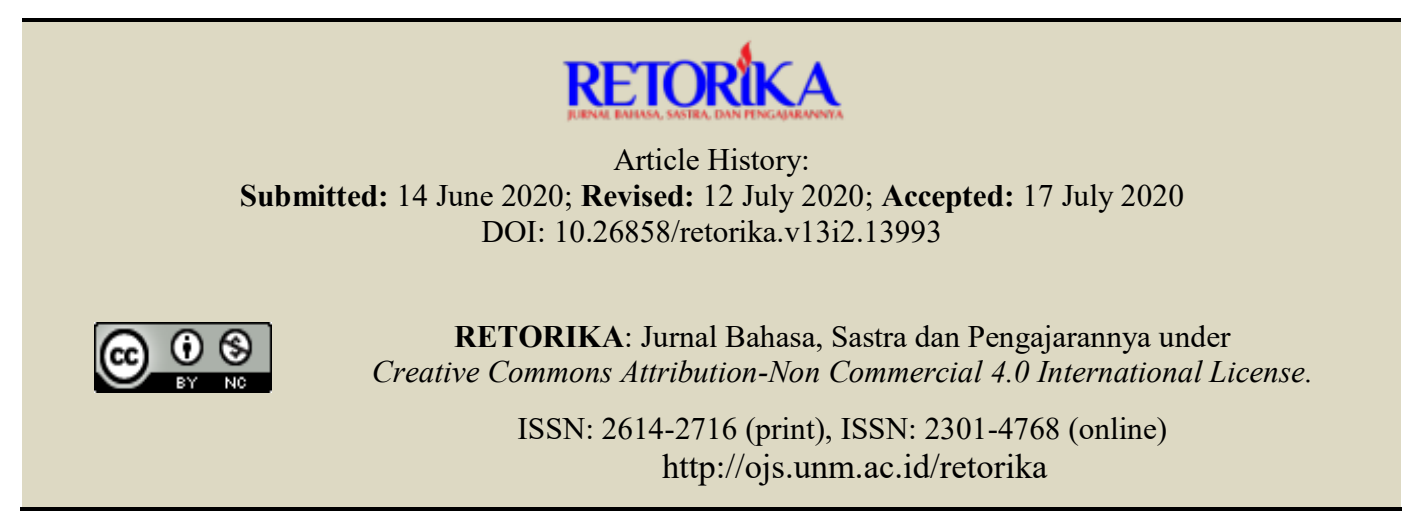

\begin{abstract}
This research was conducted to understand the perception of people in Tawangmangu, Central Java in terms of the potential of teaching TEK in primary schools, challenges, and teaching strategies. We conducted semi-structured and unstructured interviews with 77 participants (local TEK experts, local communities, educators, and education officials). TEK in Tawangmangu includes folktales, ceremonies, offerings, typical food, terraced farming, intercropping systems, irrigation systems, crop management, herbal medicine, traditional house, and social system. Participants supported the idea because the TEK began to become extinct and identified its delivery in formal schools as a bridge to maintain it. Factors identified as obstacles are limited study time, limited access to subject matter, lack of political support, and differences in the characteristics of knowledge transfer between science and TEK. Participants claimed that the most appropriate strategy for teaching it in primary schools was to bring students closer to the real context. To teach it, the teacher chooses a number of contextual learning methods that are considered suitable, like field trips, role playing, task-based learning, and project-based learning.
\end{abstract}

Keywords: traditional ecological knowledge, opprotunities, challenge, strategies teaching

As a country consisting thousands islands with diverse ethnics (Kurnilasari, Yahanan, \& Rahim, 2018), Indonesia has diverse cultures including the past culture containing adiluhung 'noble' values. The ancestral inheritance is considered noble because it contains things that are good, pure, and sincere so that it is termed local wisdom. As stated by Chaipar, Sakolnakorn, and Naipinit (2013) that local wisdom is the order of life inherited from one generation to another in the form of religion, culture, or customs. For that reasons, the exploration and actualization of old values contained in ancestor's heritage traditional cultural source is very useful to the improvement of quality of nation's mentality and personality.

More people, particularly young generation, leave traditional values for new values of foreign culture element uncertainly consistent 
with our nation's personality. Meanwhile, as the result of production domination and information diffusion by foreign state, of course, brings about and implants its cultural value (Sedyawati, 2008: 3 ). The problem is that most young generations do not realize the cultural penetration and consider everything they receive as leading them to the progress. The behavior of underestimating such the tradition values is regrettable because those values are the nation's cultural wealth that can solidify national tenacity with the spirit of Unity in Diversity.

One area that has traditional values is Tawangmangu in Central Java. In addition, this area is also known as a natural mountain tourism area. The traditional values of the people are folklore, village clean ceremonies, maintain water source ceremony, reog Pancot, various kinds of offerings, processing of offerings, herbal medicines, arrangement of offerings, procedures for processing corn rice, procedures for making offerings, procedures for growing vegetables Wati, Sumarwati, and Saddhono (2018). According to Whyte (2013) these values are moderate, becoming an international research topic in the domain of traditional ecological knowledge or traditional ecological knowledge (TEK).

TEK refers to the understanding of the overall understanding of indigenous peoples about the world (Tsuji dan Ho,2002). The term is often used in connection with oral traditions. Traditional ecological knowledge can refer to knowledge of past events, but also includes practices manifested by humans, spirituality, morality, ideology, artistic (or abstract) modes of expression, and ways in which knowledge is acquired and passed down from generation to generation (Brody, 2010).

Because of its past nature and oral tradition most of the traditional ecological knowledge in the world has become extinct (Karjala, 2012). Therefore, world organizations such as UNESCO and Non-Block suggest a resolution to make all the traditional ecological knowledge in the world today preserving their self identity (Kurnilasari, Yahanan\& Rahim, 2018). From several research results (Sumarwati, 2015; Wati, Sumarwati \& Saddhono, 2018), the same thing is also indicated to occur in the traditional values of the Tawangmangu community. Therefore, there is no extinction, it is necessary to do a variety of ways and one of them is to include traditional ecological knowledge material in learning in schools.
This research will assess the potential integration TEK into teaching and learning in primary school in Tawangmangu. The reseacher, especially, investigate current research that has been carried out on the connections between traditional ecological knowledge and western science. This undertaking is not without its challenges, but an attempt to substantiate an interpretation of traditional ecological knowledge and western science will be reinforced by exploring the epistemological and ontological underpinnings of western science and traditional ecological knowledge. By introducing traditional ecological knowledge to environmental of education programs, students would be much better equipped to examine ecological problems from a more holistic and thoughtful framework (McCarter \& Gavin, 2011; Houde, 2007). Reexamining the cultural assumptions underlying an instructor's own view of science and exposing students to a body of knowledge that connects the environment to human values could begin a process of deep learning by both teachers and students. This learning could strengthen the diversity of thought that is required to come up with new and innovative solutions to some important environmental issues.

There are three questions that must be answered in this research, namely (1) Can traditional ecological knowledge be taught in Tawangmangu primary schools? (2) What are the possible challenges in teaching traditional ecological knowledge in primary schools?, and (3) What is the strategy to teach traditional ecological knowledge in primary schools?

Defenders of TEK based resource management and environmental education rarely agree on how it should be implemented or even the appropriateness of using the knowledge of others which is based on conditions in the past (Reid, Timmey, \& Dillon, 2004: 7). But most agree that there is much to be restored in the way we view the environment and educate students about the environment. Berkes describes traditional ecological knowledge as "knowledge of the land....a fairly broad consideration of ecology, but not broad enough to encompass all aspects of knowledge" (Berkes, 2004: 5). Traditional ecological knowledge is very specific to the local ecosystems. Local ecological knowledge is based on the direct dependence on local resources over long periods of time. The intimacy between 
nature and the first inhabitants helped create an Indigenous wisdom. TEK based on observation, inference, verification, and prediction results in a world view that is very different from the science based world view.

\section{METHOD}

This research approach is a case study. According to Bogdan and Biklen (1982) a case study is a detailed test of one setting or one subject or one document storage or one particular event. While Yin (2014) provides a more technical limitation with emphasis on its characteristics. Based on these limitations it can be understood that case studies is a research strategies, empirical investigations that investigate a phenomenon in a real-life context. Case study research can mean single and multiple case studies, can include quantitative evidence, depend on various sources of evidence, and benefit from the prior development of theoretical propositions.

This research was conducted in Tawangmangu Regency, Karanganyar Regency (red circle in Figure 1), Central Java Province. The area located on the slopes of Mount Lawu is known as a beautiful natural tourist region with cool air (tends to be cold). In addition, Tawangmangu Regency also has diverse traditional ecological knowledge. Some of these cultures are still carried out by residents in the midst of the influx of urban and foreign cultures, which allows cultural degradation.

With regard to cultural diversity, Koenjaraningrat (1990) classifies it into 7 elements, namely language, knowledge systems, social systems, equipment and technology, religious systems, livelihoods, and the arts. Judging from those classification, traditional ecological knowledge treasures in Tawangmangu include (1) Mondosiyo folktale about the origin of vegetables and Dhukutan fokltale about the origin of corn food, (2) clean village traditional ceremonies, namely Dhukutan, Mondosiyo, Julungan rituals and traditional ceremonies of preserving water sources, namely Dhawuhan ritual, (3) traditional of food, cakes, places for food serving, herbal medicine, and custom house; (4) terracing farming systems, intercropping systems, irrigation systems, and harvest systems; (5) community systems such as rewang 'to help cooking' and sambatan 'to help farming'; (6) types of work, for example vegetable and decorative plants farmers, traders of glazed and decorative plants, rental of tourist horses, culinary entrepreneurs and souvenirs; and (7) performing arts which include thok prol gamelan, lumping horse dance, and Pancot reog (Sumarwati \& Anindyarini, 2019; Wati, Sumarwati, Saddhono, 2018). Meanwhile, the implementation of traditional ceremonies has added to the tourist attraction, especially in Nglurah and Pancot Village.

From the exposure of those elements, it can be identified that the cultural wealth in Tawangmangu is more related to traditional ecological knowledge in non-rice food. Therefore, all actions aimed at maintaining the sustainability of traditional ecological knowledge in Tawangma-ngu can be categorized as an effort of non-rice food security.



Figure 1. Research Location

The study was conducted in four rural communities in Tawangmangu Subdistrict, which included the villages of Kalisoro, Nglurah, Pancot, and Blumbang. Referring to Butler's recommendation (2001: 38), since traditional knowledge is not homogeneous, TEK research must involve people from different groups, so the characteristics of the participants of this research are attempted to vary from the aspects of age, gender, education, and occupation. The partici-pants were 77 people consisting of local TEK experts (prayer reader, environment coordinator, traditional ceremony leader, offerings maker, reog performers, local cultural figures) $=12$, educators (primary school teachers, religion teacher) $=21$, education officials (subdistrict edu-cation coordinator, school supervisor, principal) $=4$, and local residents $=40$. The participants included men and 
women. TEK experts are local residents aged between 50 to 76 years who work as farmers, traders, and teachers. Education participants are aged between 32 to 50 years and education officials are aged between 48 to 55 years. Local residents include people aged bet-ween 15 and 70 years consisting of farmers, traders, entrepreneurs, teachers, housewives, and students.

The selection of participants was done by using purposive sampling technique, but to select TEK experts was done by applying snowball sampling. To determine the educators who made it possible to understand the traditional ecological knowledge of non-rice food security in Tawangmangu was carried out in consultation with the village head and local environmental coordinator. To determine the teacher who has practiced local wisdom-based teaching is done through direct interviews with the principal. The selection of TEK experts was carried out through interviews with the environmental coordinator, followed by interviews with other informants appointed by the environmental coordinator, and so on, so that resource persons who truly understood the knowledge and practices of local wisdom in Tawangmangu were obtained.

To exploration about opportunities for traditional ecological knowledge taught in prima-ry schools, appropriate strategies for teaching traditional ecological knowledge in primary schools, and possible challenges faced in relation to teaching traditional ecological knowledge in primary schools, the main source of data is informan. The collection techniques applied are semi-structuredinterviews and unstructured interviews. Semistructured interviews were conducted to dig up information related to the first question, while unstructured interviews were conducted to answer the second and third questions. Interviews with TEK experts and local residents were conducted in Javanese intermediate 'medium level speech' and 'high level speech' manners to build comfort and familiarity in communication. Interviews with education officials and school teachers are conducted in Javanese and Indonesian according to the information preferences of the interviewee.

The data of this study are quantitative and qualitative data, information about opportunities and challenges of traditional ecological knowledge taught in primary schools, as well as appropriate learning strategies. The quantiative data was analyzed descriptively. The qualitative data analysis was carried out using several techniques with reference to the opinions of Cohen, Manion, \& Morrison (2007: 467-471), namely inductive analytic 'inductive analytic' constant comparison 'constant comparison', and typological analysis 'typological analysis'. Inductive analysis is the process of analyzing data by making a classification based on the data obtained, not based on the theory or the view of the researcher, then generalized as a conclusion or way of thinking from things that are specific to things that are general. Comparison of content is comparing data that has just been obtained from the informant with data that has been previously obtained from other informants, so that the process of grouping data into categories through comparison of new information with categories that have already appeared. The process of developing this category takes place gradually and slowly. The typological analysis is to group data into categories, subcategories, and/or subcategories based on certain criteria.

\section{FINDINGS AND DISCUSSION}

\section{Findings}

The results of this study include three themes as follows (1) opportunities for traditional ecological knowledge taught in primary schools, (2) possible challenges faced in relation to teaching traditional ecological knowledge in primary schools, and (3) appropriate strategies for teaching traditional ecological knowledge in primary schools.

\section{Opportunities for TEK Taught in Primary Schools}

Data from semi-structured interviews with TEK experts and local people, which in essence explore information allows whether traditional ecological knowledge about non-rice food security is offered in primary schools, shows that almost all participants ( 45 or $87 \%$ ) claim that it is very possible. The other 13\% (7 local people) said it was not possible or necessary. Semi-structured interview data on 21 teachers and 4 education officials indicate that all strongly support the integration of traditional ecological knowledge with science. Same with TEK experts, the reason is the traditional ecological knowledge of food security in Tawangmangu is truly endangered. This is related to Tawangmangu's position as a 
famous tourism area in Central Java Province. The presence of tourists, sometimes brings negative influences on local culture, for example consumption patterns of food for children who tend to prefer fast food, do not care about the environment, are not interested in agriculture, are individualistic and materialistic. In addition, the participants also stated that science combined with traditional ecological knowledge could complement each other. That is because science is universal, whereas traditional ecological knowledge is local based on the experience of ancestors survived hundreds of years, as stated by participants as follows.

\begin{abstract}
"Our ancestors have given an example that in mountainous areas it is only suitable for planting vegetables and crops, not rice. That teaching must have been obtained after undergoing trials for hundreds of years" (educator, female, 52 years old).

"The intercropping system in growing vegetables has been applied by residents here for a long time and according to science the system is indeed more profitable for farmers. So, the practices of our ancestors have knowledge" (local resident, male, 48 years old)
\end{abstract}

The participant group providing support gave two reasons. First, local wisdom practices in Tawangmangu are seen to have undergone many changes so that it is feared that in the future, the cultural wealth will change entirely, for example replacing offerings from corn with ingredients from rice, replacing encek as a place for offerings with plates or trays, and the emergence of several version of folklore about food proposals in Tawangmangu. Secondly, TEK experts point out that most TEK in Tawangmangu have begun to disappear in the last few generations, such as the culture of storytelling to children about local folklore, consuming non-rice food, participating in traditional rituals, processing corn rice in mutual cooperation. This is based on the results of the interviews which are as follows.

"When I was a child, the atmosphere of the village was so comfortable and peaceful because everything was done by the people in accordance with the prevailing customs, unlike now, young people no longer want to eat corn rice. Even though it was the legacy of their ancestors" (TEK expert, male, 72 years old ).

The disagreeing group argues that believing and practicing traditional ecological knowledge is contrary to religious teachings. They also consider that traditional things are ancient so they are not suitable to be applied in modern times. It was as stated by a participant,

\begin{abstract}
"Performing traditional rituals by making offerings violates religious teachings because it means associating partners with God. I don't want my children and other children to believe in the devil, also eat corn because it's food demon "(local resident, male, 37 years old)
\end{abstract}

Although all participants of the educator supported the integration of traditional ecological knowledge in learning science in primary schools, only $80 \%$ (20 participants) believed that primary school teachers would be successful in carrying out such integration. Their belief is based on the characteristics and demands of the 2013 Primary School Curriculum, one of which is conducting learning based on local culture. This was stated in the 2013 curriculum from grade one to grade six, as one of the educator said as follows:

\begin{abstract}
"Submission of material on local wisdom is a teacher's obligation to implement the 2013 Curriculum. That can certainly be done because the curriculum compiler must have taken into account the conditions of the field" (primary school tacher, female, 34 years old).
\end{abstract}

The group that doubts that primary school teachers, especially in rural areas, are able to conduct learning with regard to local wisdom gives two reasons. First, from the available data, some of the teachers who teach at the primary school in the Tawangmangu area come from outside Tawangmangu, so they do not understand the traditional ecological knowledge of the local community. Meanwhile, until now there has been no written material that contains the treasures of local wisdom Tawangmangu. Second, although most of the primary school teachers in Tawangmangu are state teachers, they rarely receive training in implementing the 2013 Curriculum, including how to teach local wisdom. 


\section{Challenges Faced to Teaching TEK in Primary Schools}

From the results of semi-structured interviews with participants (educators, education officials, TEK experts, local residents), which allows a source of obstacles in integrating traditional ecological knowledge in formal learning in schools includes four factors as follows teachers, students, materials, and parents. Participants highlighted various barriers to the entry of traditional ecological knowledge in formal education, especially primary schools, which can broadly be classified as practical and epistemological barriers (McCarter \& Gavin, 2011).

Practical barriers were associated with teacher competency, availability of teaching materials, availability of time, and the nature of TEK. Based on data from the Unit Pelaksana Teknis Pendidikan Sekolah Dasar Kecamatan Tawangmangu 'Primary School Technical Implementation Unit', the majority of primary schools teachers $(62 \%)$ are from and live outside the Tawangmangu area. This condition allows them to not have adequate understanding towards traditional ecological knowledge of the local area. As the following education official stated,

\footnotetext{
"Most of the primary school teachers in Tawangmangu are not native, some are not even residing here. I am afraid that the teacher cannot teach Tawangmangu's customs well" (school supervisor, female, 48 years old).
}

Sources that can be used as teaching material about traditional ecological knowledge of Tawangmangu are not many and that too must be searched through the internet. This is an obstacle for teachers, especially those with limited competence in utilizing internet technology. Adequacy of time is also an obstacle in the implementation of the TEK learning process because even without the addition of material, the learning time is insufficient. This is related to the thematic learning system applied in primary schools based on the 20113 curriculum, where subjects, time portions, and material content have been determined in the teacher and student books. Meanwhile, the questions in the exam also only revolve around the material contained in books from the government. Government policy is considered a problem by the majority of officials and teachers. In this regard, a school principal stated,

\begin{abstract}
"The key problem faced by schools in implementing the 2013 Curriculum is the lack of political support, both for teaching TEK and other teaching. For example, in the Curriculum it is stated that teachers must enrich the material, but in the exam asked only material in government books" (female, 46 years).
\end{abstract}

The TEK nature that educators are concerned about is the cultural diversity of students in one class. This is especially true in primary school environments, such as SD Negeri 5 and SDIT (Integrated Islamic Primary School) in Tawangmangu, where students come from the local and outside Tawangmangu Subdistrict in one classroom. In addition, the existence of a mythical element in traditional ecological knowledge might be a reason for educators, even parents of students, to refuse TEK teaching. Concern mainly applies to schools that are religiously affiliated.

The epistemological barriers to teaching traditional ecological knowledge are related to the delivery method. This is related to differences in learning systems, where TEK is naturally taught individually in the family, while at school it is taught classically. Educators state naturally, the transfer of traditional ecological knowledge, which is carried out individually by parents to their children (as the next generation). While in school a teacher-centered model is used, where one teacher provides knowledge to many students of various characteristics with the same material. This model is seen as contrary to the TEK system by some teachers and education officials $(50 \%)$.

They give the following examples. Local folktales are usually conveyed by mothers or grandmothers in the village as lullabies or as entertainers to children. This is justified by local people who claim that storytelling is one way for parents, after a day of work, to establish communication with their children. In fact, according to some participants, storytelling is also an educational strategy in the family. As stated by a housewife,

"I have been telling stories since my children have not spoken fluently, and in that storytelling I taught some new words by asking children to imitate these words" (local residents, female, 56 years old). 
Another epistemological barrier is related to the fact that many traditional ecological knowledge are private and held by certain family groups or individuals that may not be shared with others even if they are not confidential. For example, procedures for maintaining soil fertility, increasing production of vegetable and nutmeg plants, recipes for processing vegetables and crops, and even utilization of herbal medicine. For example, in traditional medicine, there are times when local people use herbal medicines that are known in general, such as for diarrhea, so they are considered public property and can be taught in schools. However, the treatment of more serious or specific diseases, there are times when certain herbal medicines are used that are family secrets, for example strong drugs (stamina enhancer for men), vaginal discharge for women, even cancer.

The characteristics of the traditional ecological knowledge transfer above, of course, do not apply in the western science education system. That is, science is conveyed by applying scientific ethics that every student has the same right to know everything. This is not always in line with the delivery and acquisition system habits. In addition, educators also claim there are differences in the way of teaching science and traditional ecological knowledge. At the basic level, science material is mostly in the form of theory, whereas traditional ecological knowledge requires more practice and direct observation. For example, material on how to make corn rice and encek 'tray from banan leaves' as local wisdom that is specific so that it is not sufficiently explained in theory. Also, procedures for farming and traditionally harvesting vegetables system that require enrichment through direct observation. That is one of the reasons educators do not support the teaching of traditional ecological knowledge in schools. They stated it was impossible to teach that material learning dequately in scientific and formal contexts because there were some differences in characteristics between traditional ecological knowledge and the teaching of practical skills such as the statement of one of the following teacher.

"Not all material science is factual so that primary students are sufficiently given their theories, but local wisdom knowledge involves all the real things so that not enough theory is taught" (teacher, female, 35 years).

\section{Strategies for Teaching TEK in Primary Schools}

From unstructured interviews related to traditional ecological knowledge themes that are possible to be taught to local primary school students, information delivered by TEK experts can be classified into three broad themes (borrowing Turner, Ignace \& Ignace, 2000), namely communication and exchange knowledge, worldview, practice and strategies to preserve TEK. First, communication and exchange of knowledge which includes stories of the origin of non-rice food and clean traditions of the village of Mondosiyo with offerings made from corn and tubers. Second, philosophy or worldview includes norms in behavior, life philosophy at work, in fostering harmony with fellow human beings, philosophy in treating nature, and maintaining relations with God. Third, with regard to practices and strategies for maintaining TEK sustainability, which includes procedures for selecting plants, intercropping systems, eradicating plant pests, selling crops, using medicinal plants, preserving the environment, processing corn rice, making traditional corn cakes, making encek 'trays from banana stems.

There are differences of opinion about the philosophy of life adopted by the native population can be transmitted to primary school students. Some participants (76\%) provided support for the teaching of the norms and character values applied by the ancestors. Another group expressed objections to the idea because it did not fit into this modern era. As for the support group, the reason is that not all customary norms are bad, for example the introduction of things known as "taboo" in environmental management. Taboo matters that need to be introduced to students, include (1) clearing agricultural land on Mount Lawu as a prohibited act, (2) large trees on the Menggung Site which is believed to be the tomb of Kyai Menggung is a sacred tree and abstinence to be cut down, (3) the prohibition of planting rice and having to plant corn for Nglurah farmers because the plant is believed to be the choice of his ancestors, and (4) the prohibition of putting firewood in the stove with his feet or left hand when cooking corn rice. Regarding the taboo, participants gave an explanation that a taboo must contain a hidden message that can be accepted by 
common sense, as stated by one of the following participants.

\begin{abstract}
"The prohibition on opening agricultural land in the Gunung Lawu area makes sense because if it is not banned, the forest will become bare, thus allowing a landslide disaster like what happened in 2017 "(TEK expert, male, 72 years old)

"Everything that is taboo must have a reason, only often it is not conveyed directly. That is the way of ancient character education" (local residents, female, 53 years old).
\end{abstract}

In addition to environmental norms, participants also recommended that local social norms be developed at school from an early age to increase respect for social hierarchies. Important social norms, for example, rewang and sambatan systems. The rewang system is a mutual cooperation activity (usually cooking) to prepare for a celebration, especially in the processing of corn rice and corn flour cakes at traditional ceremonies. The sambatan 'splice' system is a system of mutual cooperation among villagers by donating energy en masse to help other residents who are having a big interest such as building a house or at harvest time. An education official added that in some traditional activities contained the values of character education, so that teaching in schools is more focused on teaching values rather than specific skills. For example, being able to encek or cook corn rice is not the final goal of the teaching process, but rather on "developing patience and commitment to being able to complete the task".

When asked about the distribution of subject matter for low and high classes in primary schools, teachers and education officials group them according to basic competencies in the 2013 Curriculum and the complexity of the traditional ecological knowledge themes. According to them, from the three big themes above, a simpler classification can be made into seven domains. The three domains that are suitable for low-grade students include folklore or myths about plants, customs that are relevant to character education, and traditional rituals as performing arts. Four other relevant domains taught to high-class students include knowledge of non-rice-based foods (corn and sweet potatoes), vegetable and vegetable cropping systems (corn and sweet potatoes), medicinal plants, and environmental preservation.

There are material restrictions on the first three domains for the lower classes (folktales, customs, and traditional rituals) to accommodate fears of irregularities in terms of religious teachings. This was conveyed by local people, among others as follows,

\begin{abstract}
"We do not agree with the traditions of the past taught in primary schools because it could risk deviating from religious teachings if it is not transmitted effectively and properly translated into the school environment" ( male, 39 years old).

"In my opinion, many of the ancient customs are not in accordance with religious teachings. If it will be taught to elementary school children, the material must be selected which is fine and the teacher is trained first so that the correct way of teaching" (female, 26 years old).
\end{abstract}

Regarding traditional teaching methods of knowledge, participants recommend that teaching be in the form of theory and practice. The reason is that the transmission of traditional ecological knowledge and practices in formal education in primary schools can increase the effectiveness of intergenerational transfers, so as to make young people more concerned about the local environment, and grow a sense of ownership. This is based on the participant's statement as follows.

\footnotetext{
"The current generation does not care about local wisdom as a legacy of ancestors. The teachings and examples of parents are not heeded, so teaching that is not only theoretical is the right way to do it" (education official, male, 42 years old).

"I see young people see local wisdom as ancient, while western culture is seen as modern life. As a result, they do not care about the environment, even like damaging the environment, for example taking stones in the river to be sold so that it disrupts the irrigation of vegetable farming here. Therefore, in schools must be taught the consequences of damaging the environment, if necessary they are invited to see for themselves the damaged environment" (TEK expert, male, 65 years).
}

In addition to the above explanation, an education official (male, 54 years old) responds 
to the question of how to teach TEK effectively so that students can understand and apply good practices in maintaining non-rice food. He shared the results of his observations on how to integrate TEK into formal teaching in schools in Japan. One strategy implemented in Japan is to allow local TEK experts to come and teach TEK. This activity also realizes community participation in the school board and there is regular contact with the school authorities. The teachers stated that the knowledge and practices of indigenous peoples in the non-rice food security in Tawangmangu were real and were near schools, so TEK learning was possible by bringing students to their material sources. It was recommended by $75 \%$ of educators, as one of the following teachers stated,

"Contextual learning is usually fun and brings success, so TEK teaching must also bring students to the real context" (female, 28 years).

\section{Discussion}

As is the case with traditional ecological knowledge in Indonesia, even in the world, TEK in Tawangmangu, Central Java is also not well documented. Nakata and Langton (2005) stated that customary knowledge is usually stored in people's memories and activities and expressed in stories, songs, folklore, proverbs, dances, myths, cultural values, beliefs, rituals, community law, local languages and taxonomies, agricultural practices, equipment, materials, plant species, and animal races. That is the reason why traditional ecological knowledge treasures are easily forgotten by their owners, who eventually eventually become extinct (Nofrita, Hermawan, \& Putri, 2019). In fact, TEK can be described as the best practice in managing and treating the environment found by ancestors through their experiences for hundreds or even thousands of years. Therefore, the researchers found that TEK is a system that affects the lives of past, present, and future. Gomez-Baggethun, Corbera, \& RevesGarcia (2013) and Houde (2007) identified TEK as having a major contribution to understanding the ecological system. Wright, Wang, \& Tang (2013) also suggest a large contribution to traditional formulation of policy formulation that seeks to overcome the effects of global warming
Peow's research (2015) shows the value system in China is influenced by stories.

One way that is recommended by local communities and educators is to integrate TEK in learning in schools as conveyed by McCarter \& Gavin (2011). Therefore in various countries learning TEK in schools has been held. For example, Canada has included Aboriginal indigeneous knowledge in the education curriculum in Aboriginal children's schools (Kim, 2012). The Indonesian government also recommends that local wisdom become material in learning with the 2013 Curriculum. Based on the data description above, it can be stated that the majority of respondents (including teachers and education officials) agree to teach the wisdom of local wisdom in primary schools. There are two reasons. First, local wisdom practices are seen to have undergone many changes so that it is feared that in the future, the cultural wealth will change entirely. Secondly, most TEK in Tawangmangu have begun to disappear in the last few generations, such as the culture of storytelling to children about local folklore, consuming non-rice food, participating in traditional rituals, processing corn rice in mutual cooperation.

There are some people and teachers who have different opinions. They do not support, even forbid the implementation of the idea. Some of the reasons given are (1) things that are traditional are very close to beliefs in spirits that must be praised so as not to interfere or even can be asked for help reducing his trust in God; (2) traditional ecological knowledge does not originate from the best practices of the ancestors, but practices are based on ignorance or lack of knowledge, (3) the teaching of science that is entered by traditional elements may fail to reach the goal if the teacher does not have supporting competencies. These views are related to the dynamic characteristics of the local community which, among others, are influenced by factors such as increasing educational qualifications, technological development, population movements, economic needs, increasing individual behavior. This phenomenon also occurs in indigenous peoples of various countries. For example, Cagivinaka research (2016) found that traditional ecological 
knowledge began to be threatened by rapid population urbanization.

Even though TEK was explicitly stated to have been included in the curriculum, in its implementation there were still obstacles. The lack of consistency in national policies is of course the biggest obstacle. For example, the 2013 curriculum requires local culture-based learning, but national exam material is only about national material. Not accommodating policies regarding TEK in the national curriculum also occur in various countries. Cagivinaka (2016) found that TEK was less successful taught in Fiji because only a small portion was accommodated by the curriculum. The same thing happened in Canada that the curriculum only contained a small portion of the Aboriginal TEK values (Kim, 2012). However, Asmstrong, Kimmerer, and Vergun's research shows that among the many obstacles, an important potential that must be considered is that students want to learn more about TEK from their culture, especially on narratives and stories (2007). Some research results even show that the use of traditional ecological knowledge such as dance, games, fairy tales (Nuraini, 2018; Umbara, 2015).

The results of this study indicate traditional and local knowledge by the community owner is considered important to be taught in schools. This further strengthens the recommendations contained in the 2013 Curriculum that learning material must be appropriate to the needs of students and based on local culture. In order to respond to the demands of the 2013 curriculum, some teachers have linked their learning with local culture. Likewise, researchers have focused their studies on the use of local culture in education. However, local culture raised only on local wisdom in general, has not been focused on ecological issues. This can be attributed to the following studies.

Fitryarini, Juwita, and Purwaningsih (2014) explored the education function of local wisdom for the Dayaks. Indrianti, Khutobah, \& Latif (2017) examines local wisdom as a medium for literacy education. Several researchers (Sufia, Sumarni, \& Amirudin, 2016; Wibowo, Wasino, and Setyowati, 2012) examined the influence of local wisdom on environmental education. Other research groups use local wisdom as a source of character education values in schools (Agusman,
Suyitno, \& Pratiwi, 2018; Nuraini, 2018; Fitrahayunitisna \& Zulvarina, 2017). Thus, in Indonesia, research on local wisdom, including in education, has done a lot, but the specifics of traditional ecological knowledge have not been done much. In fact, this will support the ecoliteration movement (Kim, Vaswani, Kang, Nam, \& Lee, 2017) which is part of the School Literacy Action (Wiedarti \& Kisyani-Leksono, 2016).

\section{CONCLUSION}

We found that traditional ecological knowledge about food security in Tawangmangu made it possible to be taught in formal schools from an early age, namely primary schools in the local area. This is as one of the efforts to preserve the treasury of traditional ecological knowledge which includes folklore, traditional ceremonies, offerings, traditional food, procedures for planting, selection of vegetable and secondary crops, and medicinal plants. The integration of traditional ecological knowledge in formal education in schools has the support of the local community on the grounds that TEK which still exists today is showing extinction. Teaching strategies recommended by educators and TEK experts are to bring students into real contexts or learning must be contextual in nature. However, in its implementation, educators are not sure that they can overcome some practical and epistemological obstacles. Realizing teaching of TEK in primary schools requires a redesign of the school system to enable the dissemination of science as well as local traditional ecological knowledge supported by national and regional policies. Thus, local communities will have more flexibility to determine the content and structure of the education system, including TEK teaching. Furthermore, what is needed now is more detailed research on how to overcome the types of inhibitors that have been identified by this study. Educational reformers, humanities experts, and cultural and environmental conservation practitioners all call for the inclusion of TEK in the formal school system. However, little research has been done to test the feasibility of the idea. 


\section{REFERENCES}

Agusman, Suyitno, I., \& Pratiwi, Y. (2018). Local Wisdom and Value of Character in Level of AjiKrama at Sasak Wedding Tradition, ISLLAC: Journal of Intensive Studies on Language, Literature, Art, and Culture, 2(1): 4553.

Armstrong, M., Kimmerer, R.W., \& Vergun, J. (2007). Education and Research Opportunities for Traditional Ecological Knowledge, Frontiers in Ecology and the Environment, 5(4):12-14.

Berkes, F. (2004). Rethinking Community-Based Conservation. Conservation Biology, 18:621630.

Bogdan, R. \& Biklen, S.K.(2007). Qualitative Research for Education: An Introduction to Theories and Methods, 5th Edition, NY: Pearson

Brody, B.A. (2010). Traditional Ecological Knowledge and Intellectual Property. Kennedy Institute of Ethics Journal, 20(3): 231-249.

Butler, C. (2001) Researching Traditional Ecological Knowledge for Multiple Uses, Canadian Journal of Native Education, 28 (1): 33-47

Cagivinaka, V. (2016). Reorienting Education and Indigenous Fijian Ecological Knowledge: An Analysis of Indigenous Fijian Students' Traditional Ecological Knowledge of Environmental Sustainable Practices. International Journal of Educational Research and Development, 5(1): $10-18$.

Chaipar W, Sakolnakorn, T.P.N., \& Naipinit, A. (2013). Local Wisdom in the Environmental Management of a Community: Analysis of Local Knowledge in Tha Pong Village, Thailand, Journal of Sustainable Development, 6(2): 1722

Cohen, L., Manion, L., \& Morrison, K. (2007). Research Methods in Education, London - New York: Routledge.

Fitrahayunitisna, F., \& Zulvarina, P. (2017). The Efforts to Strengthen National Identity Through Ethical Value and Local Wisdom in Oral Literature. ISLLAC: Journal of Intensive Stu-dies on Language, Literature, Art, and Culture, 1(2): 19-23.

Fitryarini, I., Juwita, R, \& Purwaningsih. (2014). Model Literasi Media Berbasis Kearifan Lokal pada Suku Dayak Tunjung dan Dayak Benuaq di Kutai Barat, Jurnal Ilmu Sosial dan Ilmu Politik, 17(9): 207-219

Gomez-Baggethun, E., Corbera, E., \& Reves-Garcia, V. (2013). Traditional Ecological Knowledge and Global Environmental Change: Research findings and policy implications, Ecology and Society, 18(4), 72-80.
Houde, N. (2007). The Six Faces of Traditional Ecological Knowledge: Challenges and Opportunities for Canadian Co-Management Arrangements, Ecology and Society, 12(2): 34-41.

Indrianti, D. T., Khutobah, K., \& Latif, M. A. (2017). Potensi Kearifan Lokal dalam Pendidikan Keaksaraan Fungsional pada Masyarakat Perdesaan di Kabupaten Jember. Journal of Nonformal Education, 3(2): 140-148.

Karjala, D.S. (2012). Sustainability and Intellectual Property Rights in Traditional ecological knowledge. Jurimetrics 53: 57-70. International Journal of Cultural Property 18(2): 143178.

Kim, G.W., Vaswani, R.T., Kang, W., Nam, M., Lee, D. (2017). Enhancing Ecoliteracy through Traditional Ecological Knowledge in Proverbs, Sustainability, 9 (1): 1182-1198.

Kim, E.J.A. (2012). Studying the Integration Level of Traditional Ecological Knowledge in Science Education: A Case Study in British Columbia, Canada in Grade 7 and 8 Official Curriculum Documents, International Journal for CrossDisciplinary Subjects in Education (IJCDSE), 3 (2): $750-754$

Koentjaraningrat. (1990). Pengantar Ilmu Antropologi (Cetakan ke-8). Jakarta: PT Rineka Cipta.

Kurnilasari, D.T., Yahanam, A., \& Rahim, R.A. (2018). Indonesia's Traditional Ecological Knowledge Documentation in Intellectual Property Rights' Perspective, Sriwijaya Law Review, 2 (1): 110-130

McCarter, J. \& Gavin, M.C. (2011). Perceptions of the Value of Traditional Ecological Knowledge to Formal School Curricula: Opportunitiesand Challenges from Malekula Island, Vanuatu. Journal of Ethnobiology and Ethnomedicine, 7 (3): 1-14.

Nofrita, M., Hermawan, \& Putri, D. (2019). Ritual Speech of Lukah Gilo Tradition of Bonai Society: Value and Social Fungtion Text Study, Humanus, 18 (1): 80-87.

Nuraini, L. (2018). Integrasi Nilai Kearifan Lokal dalam Pembelajaran Matematika SD/MI Kurikulum 2013, Jurnal Pendidikan Matematika, 1 (2): $1-17$

Peow, S.H. (2015). Malaysian Chinese stories of hard work: Folklore and Chinese work values, International Journal of Asia Pacific Studies, 11 (2): $1-16$

Reid, A. Teamey, K., \& Dillon. J. (2004). Valuing and utilizing traditional ecological knowledge: tensions in the context of education and the 
environment, Environmental Education Research, 10 (2): 237-254

Sufia, R. S, \& Amirudin, A. (2016). Kearifan Lokal dalam Budaya Melestarikan Lingkungan Hidup (Studi Kasus Masyarakat Adat Desa Kemiren Kecamatan Glagah Kabupaten Banyuwangi), Jurnal Pendidikan: Teori, Penelitian, dan Pengembangan, 1(4): 726-731.

Sumarwati. (2015). The Traditional Dhukutan Ceremony in Tawangmangu Karanganyar Regency, Indonesia. International Indonesian Forum. 7(4): 1-11.

Tsuji, L. J. S., \& Ho, E. (2002). Traditional Environmental Knowledge and Western Science: in Search of Common Ground. The Canadian Journal of Native Studies, 22(2): 227-260.

Umbara. (2015). Integrasi Nilai-Nilai Kearifan Lokal Budaya Masyarakat dalam Pembelajaran Matematika Realistik, Kumpulan Makalah Seminar ACER-N Universitas Pasundan, 1, $25-28$

Wati, M.A., M., Sumarwati, Saddhono, K. (2018). Javanese Literature and Culture Value in Prosesion of Traditional Ceremony Dhukutan at Nglurah Village, Tawangmangu Regency, Jawa Tengah, Hortatori Journal, 2(1): 45-56

Wibowo, H., Wasino, W., \& Setyowati, D. (2012). Kearifan Lokal dalam Menjaga Lingkungan Hidup (Studi Kasus Masyarakat di Desa Colo Kecamatan Dawe Kabupaten Kudus). Journal of Educational Social Studies, 1(1).

Wiedarti, P. \& Kisyani-Laksono. (2016). Desain Induk Gerakan Literasi Sekolah. Jakarta: Kemdikbud.

Whyte, K.P. (2013). On the Role of Traditional Ecological Knowledge as a Collaborative Concept: A Philosophical Study, Ecological Processes 2013, 2 (7): 1-12.

Wright, W., Wang, Y., \& Tang, Y. (2013). Traditional Ecological Knowledge in Nontraditional Communities: A Case Study in Jiuzhaigou National Park, Journal of Park and Recreation Administration, 31(3): 77-95

Yin, R.K. (2014). Case Study Research Design and Methods (5th ed.). Thousand Oaks, CA: Sage 